\title{
Pelatihan berperilaku asertif untuk meningkatkan keterampilan prevensi tindakan bullying di SMP Islam Alma'mur Jakarta pusat
}

\author{
Lina Madila Amir \\ Program Studi Psikologi, Fakultas Sosial Bisnis, Universitas Aisyah Pringsewu \\ e-mail: bkphijau@gmail.com
}

\begin{abstract}
Abstrak. Ketidakberanian mengungkapkan secara verbal kepada perilaku bullying menjadi salah satu mengapa bullying ini terjadi berulang. Korban belum atau takut bersikap tegas karena kekhawatiran dan ketakutan bahwa kalau melawan malah akan berakibat fatal. Pelaku bullying adalah teman-teman sekelas, terkadang juga ada yang berasal dari kakak kelas dan juga teman-teman dari kelas yang lain. Dari informasi yang diperoleh salah satu siswa yang sering melakukan tindakan bullying adalah siswa yang tinggal kelas. Pelaku seringkali diintimidasi oleh siswa-siswa lainnya sehingga mereka tidak berani untuk melawan jika diejek oleh pelaku. Tujuan penelitian ini adalah untuk melatih perilaku asertif guna menimbulkan perilaku asertif dalam menghadapi bullying. Metode pre-experimental design yang digunakan adalah desain kelompok tunggal One group pre test-post tes design. Sample yang digunakan dalam pelatihan ini adalah sample kecil ( $n$ ) yaitu 22 orang siswa Sekolah SMP. Modul pelatihan berisi tentang teknik berperilaku asertif untuk meningkatkan perilaku asertif terhadap tindakan bullying. Evaluasi pelatihan menggunakan tipe - tipe evaluasi berdasarkan Pemahaman/reaksi, Pengatahuan dan keterampilan serta perubahan perilaku. Hasil analisis data terhadap pernyataan responden secara rata-rata pada sebaran data sebelum pelatihan terlihat bahwa untuk responden yang memberikan penilaian sangat sering dengan rata-rata 11, untuk responden yang memberikan penilaian sering dengan rata-rata 6 dan yang memberikan penilaian jarang dengan rata-rata 4 adapun responden yang memberikan penilaian sangat jarang dengan rata-rata 1. Bila melihat hasil secara keseluruhan ratarata pada sebaran data sebelum pelatihan terlihat nilai tertinggi dengan rata-rata sebesar 11 nilai rata-rata tersebut berada pada kategori sangat sering, sehingga dapat disimpulkan bahwa perilaku asertif sangat baik. Sekolah dapat memberikan bekal ketrampilan sosial dan kesiapan mental bagi siswa melalui kegiatan training atau pelatihan secara berkala dan bekerjasama dengan lembaga profesional sehingga dapat memberi manfaat bagi kesiapan psikologis siswa.
\end{abstract}

Kata kunci: Perilaku Asertif, Bullying, remaja, kepercayaan diri.

\section{Pendahuluan}

Bullying masih menjadi suatu fenomena gunung es di dunia pendidikan Indonesia. Beberapa kali media massa dan elektronik memuat berita tentang kasus bullying yang terjadi di sekolah. Survei mengenai gambaran bullying di Indonesia pernah dilakukan oleh Juwita (dalam Amawidyati, 2010) yang melakukan penelitian di tiga kota yaitu Yogyakarta, Jakarta, dan surabaya terhadap 1500 anak. Berdasarkan hasil penelitian ditemukan data bahwa Yogyakarta mencatat angka bullying tertinggi yaitu 70,65\% dibanding Jakarta dan Surabaya.

Menurut KPAI, saat ini kasus bullying menduduki peringkat teratas pengaduan masyarakat. Dari 2011 hingga agustus 2014, KPAI mencatat 369 pengaduan terkait masalah tersebut. Jumlah itu sekitar 25\% dari total pengaduan di bidang pendidikan sebanyak 1.480 kasus. Bullying yang disebut KPAI sebagai bentuk kekerasan di sekolah, mengalahkan tawuran pelajar, diskriminasi pendidikan, ataupun aduan pungutan liar (Republika, Rabu 15 oktober 2014) 
Ketidakberanian mengungkapkan secara verbal kepada perilaku bullying menjadi salah satu mengapa bullying ini terjadi berulang. Korban belum atau takut bersikap tegas karena kekhawatiran dan ketakutan bahwa kalau melawan malah akan berakibat fatal. Mengabaikan dan mendiamkan menjadi pilihan bagi para korban bullying untuk menghindari masalah baru, padahal justru dengan mendiamkan maka perilaku bullying akan semakin menjadi.

Di Jakarta, khususnya di SMP Islam Alma'mur Jakarta terjadi beberapa kasus bullying yang sebagian besar tidak dilaporkan siswa kepada guru. Siswa lebih memilih diam agar tidak menimbulkan masalah baru. SMP Islam Alma'mur Jakarta terletak di pusat kota Jakarta tidak jauh dari stasiun Cikini dan padat penduduk. Sebagian siswa berasal dari lingkungan sekitar sekolah.

Dari hasil wawancara yang dilakukan oleh peneliti pada guru Bimbingan Konseling (BK) di SMP Islam Alma'mur Jakarta bahwa beberapa kali guru menerima laporan adanya perilaku siswa yang mengganggu siswa yang lain. Bentuk-bentuk perilaku yang sering masuk laporan di ruang BK diantaranyan adalah adanya siswa yang dimintai uang oleh siswa siswa lainnya, sepeda dikempesi, memanggil dengan julukan yang jelek atau nama orangtua hingga memukul. Peristiwa-peristiwa ini terjadi selama kurun waktu satu semester. Guru memprediksi bahwa masih ada tindakan-tindakan bullying yang dilakukan yang mungkin tidak sampai dilaporkan kepada guru.

Guru mengatakan bahwa pengawasan terhadap perilaku siswa memang belum dapat diterapkan secara ketat. Hal ini dikarenakan jumlah siswa yang cukup banyak sementara jika terjadi perilaku bullying biasanya siswa yang menjadi korban tidak berani untuk melaporkan kejadian tersebut dikarenakan merasa takut diancam oleh si pelaku.

Hasil wawancara dengan salah satu siswa SMP Islam Alma'mur Jakarta yaitu (SN) diperoleh informasi bahwa ada beberapa orang siswa yang mengalami tindakan bullying dari siswa lainnya. Bentuk-bentuk ejekan yang sering dia terima adalah yang berhubungan dengan fisiknya, misalnya dipanggil gendut, atau cebol atau kriwil. Ada juga bentuk ejekan dengan memanggil nama julukan yang jelek atau dengan nama orangtua, ada yang dipanggil dengan panggilan seksis seperti panggilan OLGA, karena dianggap berperilaku seperti perempuan. Selain dia, ada juga teman-temannya yang diperlakukan seperti itu. Bahkan ada yang sampai dipalak untuk dimintai uang jajan. Ada juga siswa yang seringkali dipukul karena dipaksa untuk menuruti perintah dari pelaku. Pernah suatu saat pelaku meminta untuk mengerjakan tugas sekolah kepada siswa. Karena tidak mau mengerjakan perintahnya pelaku malah memukul dan "mengata-ngatai" dengan istilah-istilah yang buruk. karena merasa takut dia diam saja dan tidak berani melaporkan perilaku tersebut kepada guru. saat diejek ada juga siswa yang membalas dengan gantian mengejek si pelaku. Akhirnya pelaku menantang untuk berkelahi dan memukul si siswa tersebut.

Dari wawancara dengan salah seorang siswa puteri yang menjadi korban bullying diperoleh informasi bahwa bentuk perlakuan bullying yang sering diterima adalah dikatakan "Jablay", bahasa prokem yang artinya perempuan genit dan murahan seperti PSK (Pekerja Seks Komersial ), selain itu juga seringkali dirinya dikucilkan dari teman-teman lainnya. Seringkali juga dirinya dibilang cewek lebay, padahal dirinya tidak merasa sebagai cewek yang lebay. Dia merasa tidak memiliki teman disekolah karena teman-temannya yang lain seringkali terkesan seperti menghindar untuk bermain dengan dirinya. Dia merasa sedih dengan kondisi yang dialaminya dan merasa tidak berdaya dengan perlakuan dari teman-temannya.

Pelaku bullying adalah teman-teman sekelas, terkadang juga ada yang berasal dari kakak kelas dan juga teman-teman dari kelas yang lain. Dari informasi yang diperoleh salah satu siswa yang sering melakukan tindakan bullying adalah siswa yang tinggal kelas. Pelaku seringkali diintimidasi oleh siswa-siswa lainnya sehingga mereka tidak berani untuk melawan jika diejek oleh pelaku. Tempat tempat yang sering digunakan biasanya adalah kantin sekolah, didepan kelas, dikelas saat tidak ada 
guru yang mengajar, didepan sekolah saat jam sekolah berakhir, di belakang Musholah, diparkiran kendaraan atau tempat tempat lain yang tidak ada guru atau pegawai sekolah yang mengawasi.

Rigby (dalam Astuti 2008 ), siswa mengaku tidak berani untuk melawan karena merasa takut dengan si pelaku. Biasanya mereka hanya diam saja ketika mendapatkan tindakan bullying dari pelaku. Jika membalas biasanya pelaku akan semakin di bully oleh pelakunya. Ada juga siswa puteri yang diejek hingga menangis karena dikatakan " genit ", siswa tersebut seringkali dikucilkan dan dimusuhi oleh salah satu kelompok dan menjadi korban gosip oleh kelompok yang memusuhinya, padahal dia merasa tidak mempunyai salah terhadap mereka.

Peneliti pada hari Sabtu, 31 Januari 2015 melakukan diskusi kelompok dengan siswa di SMP Islam Alma'mur Jakarta sepulang mereka dari sekolah yang mana terdiri dari siswa yang menurut guru BK diduga merupakan korban bullying dan juga berdasarkan informasi yang diterima dari beberapa siswa yang lain.

Dari hasil diskusi kelompok diperoleh informasi bahwa mereka seringkali mendapatkan tindakan bullying dari teman sekelasnya ataupun dari teman yang berbeda kelas. Bentuk perilaku bullying yang sering muncul adalah dengan memanggil nama dengan julukan yang buruk, memanggil nama orang tua dan menyebar-nyebarkan gosip kepada teman-teman yang lain. Ada juga yang di bentak karena disuruh untuk melakukan sesuatu oleh pelaku. Siswa yang lain seringkali dikucilkan dari pergaulan dengan teman-teman di sekolah dan seringkali digosipkan dengan berita yang tidak baik, dipaksa untuk mengerjakan tugas-tugas sekolah. Perlakuan ini seringkali mereka alami. Hampir setiap hari mereka dipanggil dengan nama yang tidak baik. Saat mendapatkan perilaku tersebut seringkali mereka menjadi marah dan membalas pelaku. Namun hal itu tidak menghentikan pelaku malah semakin membuat pelaku marah dan semakin mengejek siswa yang di bullying.

Dari hasil wawancara dan diskusi kelompok yang sudah dilakukan dapat disimpulkan bahwa permasalahan bullying di SMP Islam Alma'mur Jakarta sudah kerap kali terjadi. Pelaku biasanya merupakan siswa yang dianggap "jagoan" disekolah dan ada pula siswa yang tinggal kelas sehingga dirinya merasa berkuasa untuk bertindak semaunya. Biasanya yang dilakukan adalah mengejek dengan kata-kata yang berhubungan dengan anggota tubuh korban korban atau menghubungkan dengan latar belakang keluarga si korban. Korban akan merasa terkucilkan dan tidak sanggup untuk melawan karena jika melawan biasanya perlakuan bullying yang diterima akan semakin parah. Yang dilakukan biasanya hanya diam saja dan terkesan pasrah dengan perlakuan dari pelaku bullying. Mereka tidak berani melapor kepada guru karena takut dengan ancaman dari pelaku yang mengatakan jika melaporkan kepada guru maka akan dihajar. Ternyata dengan memilih untuk diam tidak membuat mereka bebas dari bullying. Mereka tetap diejek dan ditakut-takuti oleh pelaku.

Pihak guru sendiri merasa kesulitan untuk dapat selalu mengontrol aktifitas yang dilakukan oleh siswa. Selain karena beban kerja yang sudah cukup berat, dari siswa sendiri seringkali tidak mau melaporkan kepada guru saat mereka di bully oleh temannya.

Untuk menyikapi masalah tersebut maka siswa-siswa yang sering menjadi koran bullying perlu untuk diberikan sebuah keterampilan baru yang nantinya akan berguna bagi dirinya saat menghadapi situasi bullying. Dengan keterampilan yang dimilikinya, korban bullying memiliki kemampuan untuk melindungi dirinya sendiri saat menghadapi situasi bullying.

Bullying adalah sebuah hasrat untuk menyakiti. Hasrat ini diperlihatkan ke dalam aksi, menyebabkan seseorang menderita. Aksi ini dilakukan secara langsung oleh seseorang atau kelompok yang lebih kuat, tidak bertanggung jawab, misalnya berulang, dan dilakukan dengan perasaan senang. Selanjutnya Pelaku bullying memiliki karakteristik yang berbeda dengan korban.

Coloroso (2007) menyebutkan beberapa karakteristik anak yang rentan menjadi korban bullying (penindasan) adalah anak yang baru dilingkungan tersebut, anak termuda di sekolah, anak yang pernah mengalami trauma, anak penurut, anak yang perilakunya dianggap mengganggu orang lain, 
anak yang pemalu, anak yang miskin atau kaya, anak yang suku ras etnisnya dipandang inferior oleh penindas, anak yang cerdas, berbakat atau memiliki kelebihan, anak gemuk atau kurus, anak yang memiliki ciri fisik yang berbeda dengan orang lain. Anak dengan ketidakcakapan mental atau fisik, dan anak yang berada pada di tempat yang keliru pada saat yang salah.

Apabila anak telah menjadi korban bullying (penindasan), anak tidak akan memberitahukan kepada orang lain secara terus terang. Ada beberapa alasan anak tidak mau berterus terang tentang hal tersebut, diantaranya (Coloroso, 2007) a) Merasa malu karena pernah ditindas; b) Takut akan aksi balas dendam; c) Mereka berfikir tidak ada orang yang dapat menolong mereka; d) Mereka tidak berfikir kalau ada orang yang akan menolongnya.

Tobler (dalam Santrock, 2003) menyatakan bahwa kemampuan untuk bertahan terhadap tekanan sebaya merupakan salah satu kemampuan yang harus dimiliki remaja dalam menolak kenakalan remaja. Untuk mencegah dampak negatif dari pergaulan dengan teman sebaya tersebut remaja perlu menumbuhkan asertivitas. Kirschenbaum (1995) menjelaskan bahwa kemampuan menolak tekanan teman sebaya merupakan salah satu aplikasi asertifitas.

Asertif ini dapat dipelajari dan dikembangkan melalui pelatihan. Hasil penelitian yang dilakukan oleh Novalia dan Dayakisni (2013) menunjukkan ada hubungan negatif yang sangat signifikan antara perilaku asertif dengan kecenderungan menjadi korban bullying. Hal ini berarti semakin tinggi perilaku asertif siswa maka semakin rendah kecenderungan menjadi korban bullying, demikian juga sebaliknya, semakin rendah perilaku asertif maka semakin tinggi kecenderungan menjadi korban bullying.

Asertifitas perlu diberikan kepada korban bullying. Asertifitas mampu menghambat efek negatif dari pengaruh stress yang dialami seseorang. Karena seseorang yang asertif mampu menghadapi peristiwa yang tidak menyenangkan dengan sukses menggunakan strategi yang efektif (Wade, 2007). Pelatihan asertif akan membantu korban menjadi lebih berani untuk mempertahankan haknya dan tidak merasa bersalah ketika mempertahankan haknya (Fox \& Bolton dalam Rini, 2008). Pada pelatihan asertifitas korban bullying diajarkan strategi yang tepat untuk menghadapi peristiwa bullying yaitu merespon dengan menunjukkan sikap tenang dan mengabaikan perilaku serta tidak merespon perilaku bullying secara agresif maupun pasif (Orpinas \& Horne, dalam Rini 2008).

Berdasar pemaparan yang telah ditulis, maka dipandang perlu adanya pelatihan asertivitas di SMP Islam Alma'mur Jakarta sebagai langkah prevensi terhadap perilaku bullying yang dilakukan oleh teman sekelasnya maupun yang dilakukan oleh kakak kelas. Dengan memiliki keterampilan bersikap asertif, siswa yang sering mengalami tindakan bullying akan memiliki keterampilan untuk melepaskan diri dari situasi tersebut walaupun tanpa mendapat pertolongan dari guru.

\section{Metode}

Penelitian ini dilakukan melalui pendekatan kuantitatif dan pendekatan kualitatif. Pendekatan kuantitatif adalah pendekatan penelitian dengan menggunakan angka dalam analisanya. Pendekatan kuantitatif dilakukan untuk mendapatkan informasi mengetahui hubungan antar variabel yang ada dalam organisasi (Smither, Houston \& Mclntire, 1996). Dalam pendekatan kuantitatif, penelitian dilakukan dengan memberikan kuesioner kepada responden penelitian. Sementara pendekatan kualitatif adalah pendekatan penelitian dengan menggunakan data yang bersifat deskriptif (Poerwandari, 2009). Pendekatan kualitatif dalam penelitian ini dilakukan dengan melakukan wawancara. 
Metode penelitian dalam pelatihan ini adalah metode pre-experimental design. Bentuk dan metode pre-experimental design yang digunakan adalah desain kelompok tunggal One group pre testpost tes design yaitu memberikan pre test kemudian memberikan perlakuakan secara sengaja dan sistematis terhadap satu kelompok, berupa perlakuan pembelajaran melalui metode pemberian pelatihan dan post test atau evaluasi hasil belajar pada akhir pembelajaran.

Sample yang digunakan dalam pelatihan ini berjumlah 22 orang. Sedangkan untuk mengetahui hasil dari pre test dan post test dalam pelatihan ini CP mengolah data dengan teknik statistik T-tes dengan menggunakan SPSS for windows versi 20.0. Penggunaan teknik t-tes ditujukan untuk melihat sampai di mana peserta dapat mempertahankan hasil pelatihan, yaitu setelah dua bulan sejak mengikuti pelatihan.

Pelaksanaan pelatihan perilaku asertif terhadap bullying ini dilakukan satu hari, pada sabtu 14 Februari 2015 dari pukul 08.00 wib sampai dengan 17.00 wib (durasi 9 jam) di ruangan kelas VIII SMP Islam Alma'mur Jakarta. Di dalam penelitian ini peneliti menggunakan analisis uji $\mathrm{t}$ untuk dua sampel yang berpasangan (paired sample $t$ test) dengan menggunakan Program SPSS (Statistical Product and Service Solution) Version 20.00. Uji $\mathrm{t}$ untuk dua sampel yang berpasangan (paired sample $t$ test) digunakan untuk pengujian perbandingan dua sampel yang berpasangan atau diartikan sebuah sampel dengan subjek yang sama namun mengalami dua perlakuan atau pengukuran yang berbeda.

\section{Hasil dan Pembahasan}

Hasil analisis data terhadap pernyataan responden secara rata-rata pada sebaran data sebelum pelatihan terlihat bahwa untuk responden yang memberikan penilaian sangat sering dengan rata-rata 11, untuk responden yang memberikan penilaian sering dengan rata-rata 6 dan yang memberikan penilaian jarang dengan rata-rata 4 adapun responden yang memberikan penilaian sangat jarang dengan rata-rata 1. Bila melihat hasil secara keseluruhan rata-rata pada sebaran data sebelum pelatihan terlihat nilai tertinggi dengan rata-rata sebesar 11 nilai rata-rata tersebut berada pada kategori sangat sering, sehingga dapat disimpulkan bahwa perilaku asertif sangat baik.

Sebaran data setelah pelatihan terlihat bahwa untuk responden yang memberikan penilaian sangat sering dengan rata-rata 13 , untuk responden yang memberikan penilaian sering dengan rata-rata 5 dan yang memberikan penilaian jarang dengan rata-rata 3 adapun responden yang memberikan penilaian sangat jarang dengan rata-rata 1. Bila melihat hasil secara keseluruhan rata-rata pada sebaran data setelah pelatihan terlihat nilai tertinggi dengan rata-rata sebesar 13 nilai rata-rata tersebut berada pada kategori sangat sering, sehingga dapat disimpulkan bahwa setelah diadakan pelatihan peningkatan perilaku asertif meningkat dari rata-rata 11 menjadi 13 dan tentunya pelatihan tersebut sangat baik.

Hasil uji t-test terhadap variabel pelatihan dalam menghadapi bullying diperoleh rerata pre test sebesar 209.4545 dengan standar deviasi 48,02353 sedangkan rerata hasil posttest sebesar 220,4545 dengan standar deviasi 45.24087.

\section{Tabel 1}

Paired Samples Statistics

\begin{tabular}{lllrrr}
\hline & Mean & N & Std. Deviation & Std. Error Mean \\
\hline \multirow{2}{*}{ Pair 1} & Sebelum Pelatihan & 209,4545 & 22 & 48,02353 & 10,23865 \\
\cline { 2 - 5 } & Sesudah Pelatihan & 220,4545 & 22 & 45,24087 & 9,64538 \\
\hline
\end{tabular}


Tabel 2

Paired Samples Correlation

\begin{tabular}{lllll}
\hline & & N & Correlation & Sig. \\
\hline Pair 1 & Sebelum \& Sesudah Pelatihan & 22 & \multirow{2}{*}{, 985} & \\
\hline
\end{tabular}

Ada korelasi antara data sebelum pelatihan dengan data sesudah pelatihan sebesar 0.985 dengan taraf signifikansi 0.000 dengan dibawah 0,05. Hasil uji-t pelatihan asertif terhadap bullying dapat dilihat dalam tabel berikut ini:

Tabel 3

Paired Samples test

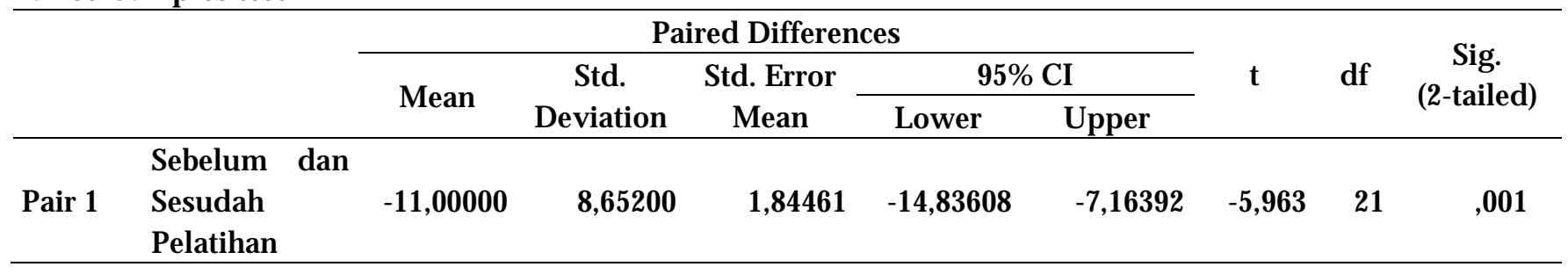

Tabel 3 menunjukkan bahwa ada perbedaan yang signifikan antara peningkatan rata-rata dalam menghadapi bullying sebelum pelatihan dan sesudah pelatihan. Peningkatan rata-rata dalam menghadapi bullying sesudah pelatihan lebih tinggi daripada sebelum pelatihan. Dengan rerata $11,00000, t=-5.963$ dengan taraf signifikansi 0.001 .

Berdasarkan hasil perhitungan uji hipotesis tentang beda dua rata-rata, diperoleh nilai thitung sebesar -5,963 dan nilai tabel sebesar -2,018. Dengan demikian nilai t-hitung > nilai t-tabel $(-5,963>-$ 2,018), sehingga hipotesis menyatakan bahwa terdapat perbedaan perilaku dalam menghadapi bullying di SMP Islam Alma'mur Jakarta sebelum dan setelah mengikuti pelatihan perilaku Asertif.

Setelah pelatihan berperilaku asertif untuk meningkatkan perilaku asertif terhadap tindakan bullying ini telah melalui proses, maka pelatihan ini mengacu pada dua macam evaluasi, yaitu evaluasi peserta dan evaluasi program.

\section{Evaluasi Peserta}

Evaluasi peserta dilakukan untuk mengetahui peningkatan pengetahuan pesertaa mengenai bagaimana berperilaku asertif dalam menghadapi bullying yang ada di sekolah maupun di luar sekolah. Evaluasi ini dilakukan dengan cara membandingkan hasil skor yang diperoleh dari pre-test atau tes sebelum diberikan pelatihan dengan hasil skor yang diperoleh dari post - test atau tes sesudah mengikuti pelatihan. Skor tiap peserta diperoleh dari skala perilaku asertif yang peneliti sebar sebelum dan sesudah dilakukan pelatihan sebanyak 66 pernyataan.

\section{Evaluasi Program}

Evaluasi program diperoleh dari lembar evaluasi yang telah diberikan kepada peserta pelatihan, di mana setiap peserta memberikan evaluasi terhadap proses pelatihan yang telah dilaksanakan. Evaluasi pelatihan meliputi kemampuan trainer, materi atau modul pelatihan serta metode pelatihan, pelaksanaan pelatihan, fasilitas dalam pelatihan, serta peserta memberikan kesan dan saran untuk pengembangan pelatihan seperti :.

Evaluasi pertama mengenai kesesuaian pelatihan dengan harapan peserta dimana 22 orang menyatakan bahwa pelatihan yang diberikan mengenai perilaku asertif menghadapi bullying sangat Hasil Hipotesis 
Hasil penelitian ini menunjukkan bahwa siswa yang mengikuti pelatihan asertivitas mengalami peningkatan kepercayaan diri dalam menghadapi bulliying. Hasil penelitian ini sesuai dengan pendapat Lauster (2000); Mukhlis, (2016) bahwa kepercayaan diri merupakan suatu sikap atau yakin atas kemampuan diri sendiri sehingga dalam tindakan-tindakannya tidak terlalu cemas, merasa bebas untuk melakukan hal-hal yang sesuai keinginan dan tanggung jawab atas perbuatannya, sopan dalam berinteraksi dengan orang lain, memiliki dorongan prestasi serta dapat mengenal segala kekurangan dan kelebihannya.

Menurut Meistari (1995) bahwa remaja yang memiliki kepercayaan diri akan bertindak mandiri, dengan membuat pilihan dan mengambil keputusan sendiri seperti menjalin relasi dengan orang lain, memiliki tanggung jawab dimana remaja mampu bertindak dengan segera dengan penuh keyakinan dan memiliki persepsi diri yang positif, sehingga merasa bangga atas prestasinya, mendekati tantangan baru dengan penuh antusias, dan mau melibatkan diri dengan lingkungan yang lebih luas, kasih sayang spontan serta mampu mempengaruhi orang lain dan bersikap asertif.

\section{Kesimpulan dan Saran}

Hasil uji hipotesa penelitian dengan uji beda dua rata-rata menunjukkan bahwa terdapat perbedaan perilaku dalam menghadapi bullying di SMP Islam Alma'mur Jakarta sebelum dan setelah mengikuti pelatihan perilaku Asertif. Hal ini berarti assertion training efektif terhadap asertivitas siswa. Perubahan asertivitas siswa terjadi karena ada proses perbaikan pola pikir yang keliru dengan menggunakan prinsip terapi kognitif, dan ada perbaikan perilaku melalui proses role play dan simulasi dengan menggunakan prinsip terapi perilaku. Jadi dapat disimpulkan bahwa pelatihan asertivitas efektif untuk meningkatkan kepercayaan diri siswa.

Sekolah dapat memberikan bekal ketrampilan sosial dan kesiapan mental bagi siswa melalui kegiatan training atau pelatihan secara berkala dan bekerjasama dengan lembaga profesional sehingga dapat memberi manfaat bagi kesiapan psikologis siswa. Berdasarkan hasil penelitian ini dapat disarankan bahwa pelatihan asertivitas merupakan salah satu solusi bagi bagi mahasiswa untuk mengatasi hambatan kepercayaan diri.

\section{Daftar Pustaka}

Astuti, P.R. (2008). Meredam Bullying; 3 Cara Efektif Menanggulangi Kekerasan Pada Anak. Jakarta: Kompas Gramedia.

Arthur I. Lange, Patricia Jakubowski: Responsible Assertive Behaviour: Cognitive/Behavioural Procedures for Trainers

Azwar. S.2005. Dasar - Dasar Psikometri. Yogyakarta: Pustaka Pelajar.

Bloom.BS (1975 ) Tazonomy Of Education Objectives Cognitive Domain, New York : David MC.Kay

Coloroso, B. 2007. Stop Bullying (Memotong Rantai Kekerasan Anak Dari Prasekolah Hingga SMU). Jakarta: PT. Ikrar Mandiri Abadi.

Kaplan, R.M., \& Saccuzzo, D.P. (2005). Psychological Testing : Principles Application E Issues (3rd Ed). California : Brooks /Cole Publishings.

Kirkpatrick, Donald.L \& Kirkpatrick, James.D. (2007). Implementing The Four Levels : A Practical Guide For 
Effective Evaluation Of Training Programs. SanFransisco : Berrett-Koehler Publisher, Inc.

Kumar, R. (2005). Research Methodology: A Step-by-Step Guide for Beginners. Malaysia: Sage Publications.

Kroehnert, G.1995. Basic Training for Trainer. Australia : McGraw - Hill Book

Lange, Arthur.J \& Jakubowski, Patricia. (19981 Responsible Assertive Behavior Cognitive/Behavioral Procedures for Trainers. Illinois : Research Press.

Lawrence M. Miller. 1987. Manajemen era baru : beberapa pandangan mengenai budaya perusahaan modern alih bahasa Windrojo

Mukhlis, H., \& Koentjoro, K. (2016). Pelatihan Kebersyukuran untuk Menurunkan Kecemasan Menghadapi Ujian Nasional pada Siswa SMA. Gadjah Mada Journal of Professional Psychology (GamaJPP), 1(3), 203-215. doi: https://doi.org/10.22146/gamajpp.9395

Newstrom, John W. Davis, Keith E. Organizational Behavior : Personnnel Management. Penerbit: McGraw-Hill: 1989

Novalia., Dayakisni, T. 2013. Perilaku Asertif Dan Kecenderungan Menjadi Korban Bullying. Universitas Muhammadiah Malang. Thesis: Tidak diterbitkan

Olweus, Dan. 1993. Bullying At School: What We Know and What W e Can Do Understanding Children's Worlds. Oxford, UK \& Cambridge, USA :Blackwell Publishing Ltd.

Poerwandari, E.K. (2009). Pendekatan Kualitatif untuk Penelitian Perilaku Manusia. Depok: LPSP3.

Rakos, F. R. (1991). Assertive Behaviour. New York: Roubledge Chapman \& Hall, Inc.

Rigby. Ken. 2007. Bullying in schools: and what to do about it. Australia: ACER Press

Rini, B. D. C. 2008. Pelatihan asertif untuk korban bullying pada siswa sekolah dasar. Thesis: Tidak dipublikasikan

Santoso, V. E., Mulyani, I. M. 2008. 100 Permainan Kreatif Untuk Outbound dan Training. Yogyakarta: Andi Offset

Santrock, J. (2003). Adolescence Perkembangan Remaja. Editor: Adelar, S., \& Saragih, S. Jakarta: Penerbit Erlangga.

Supratiknya, A. 2011. Merancang Program dan Modul Psikoedukasi Edisi Revisi. Yogyakarta: USD

Tight. G (1996) [on line]. Tersedia di http:/hd.shvoong.com/tags/teaching/

Yuliaty, F., Purnama, Y., Akbar, F. M., Mukhlis, H., \& Irviani, R. (2020). Behavioristic Psychology of the Modern Constitution. Journal of Critical Reviews, 7(8), 2019-2023. 